\title{
UPAYA PENINGKATAN PROFESIONALISME GURU MELALUI KEGIATAN KELOMPOK KERJA GURU PENDIDIKAN AGAMA ISLAM DI KECAMATAN SAMIGALUH, KABUPATEN KULON PROGO
}

\author{
Akhiru Nurul Umah \\ Penyuluh Agama Islam Fungsional Kec.Girimulyo Kab.Kulon Progo \\ akhiru_nurul@yahoo.co.id
}

\section{Abstract}

As instructors, counselors, and educators, teacher determine learners' changes. Therefore, teacher must continue to improve their knowledge, skills, and experience. They need a forum to develop their professionalism. KKG of Teacher Working Group is an ideal forum for developing teacher professionalism. In KKG, teacher will gain a lot of benefits, such as: improving their skills in managing Islamic Education teaching-learning activities, developing their ability to implement various teaching-learning models, helping teachers to fulfill teaching-learning activity requirements, helping teachers to obtain educative, technical information about Islamic Education, and improving their educational insights as well as exchanging information and experience. The study is a field of research using qualitative research. That implements observation, interview, and documentation method. The data collections used data validity tri anggulansi and sampling technique, while the data analysis applies qualitative, descriptive technique, which is collecting purposive sample and analyzing the data, reducing the data, and concluding (drawing conclusions). The result shows that the activities of Islamic Educations Teacher Working Group have corresponded to the exciting guidelines of Teaching Working Group activities. The teachers in this Islamic Education Teacher Working Group have possessed professional competence. It can be seen from the excellent teaching-learning quality of the Islamic Education subject. Teachers' professional competence cannot be separated from several aspects that are promoted and implemented during the development of professional competence of Islamic Education Teacher Working Group in the level of sub-district. The activities of Teacher Working Group are also influenced by supporting factors and limiting factors. These factors also include internal and external aspects. 


\section{ملخص}

كالمدربين والمستشارين والمعلمين، المعلمون يحددون تغييرات المتعلمين. لذلك، يجب

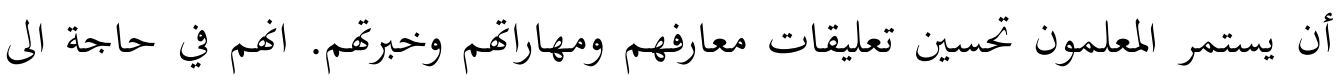

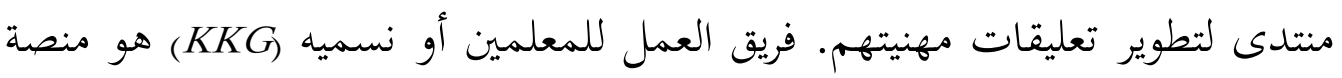
مثالية لتطوير احتراف المعلمين. في (KKG)، يحصل المعلمون على الكثير من الفوائد،

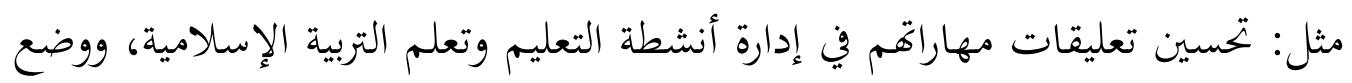
تعليقات قدرةما على تنفيذ مختلف نماذج التعليم والتعلم، ومساعدة المعلمين للوفاء

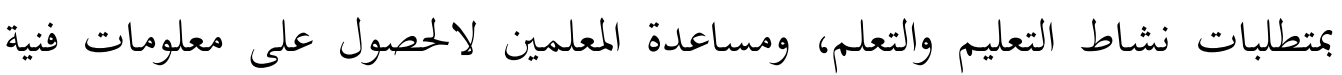

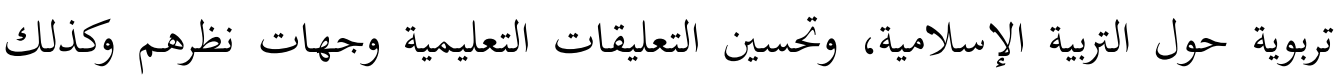

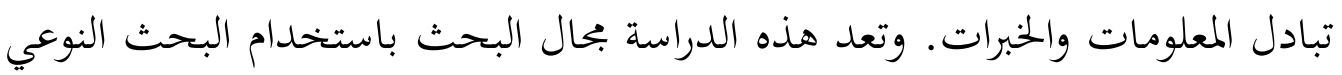

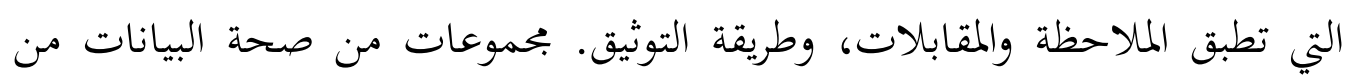

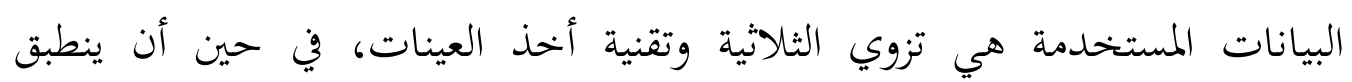

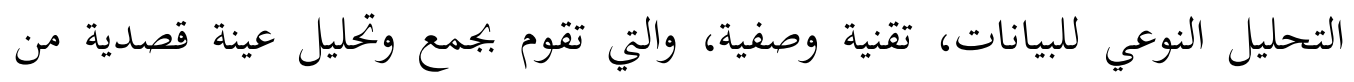

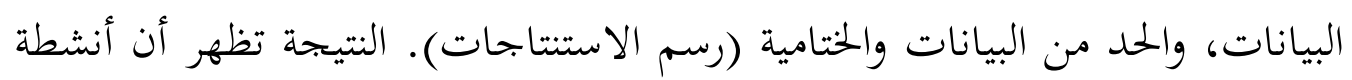

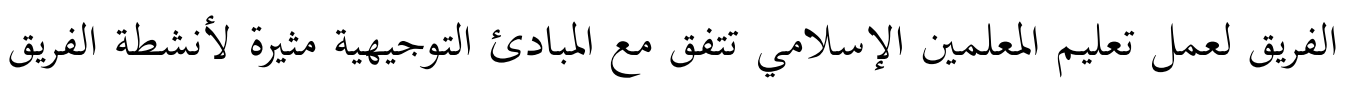

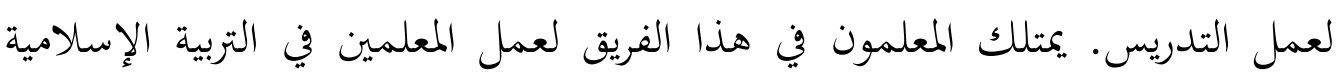

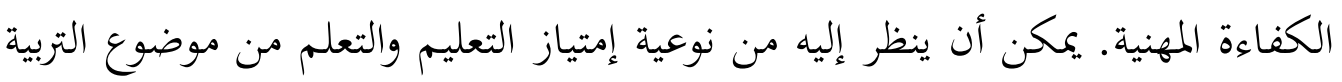

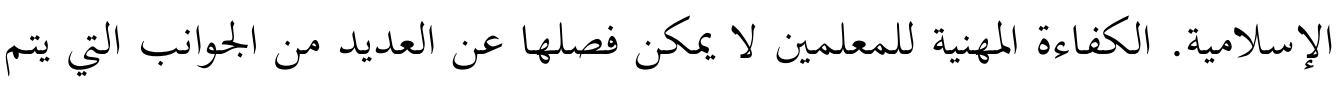

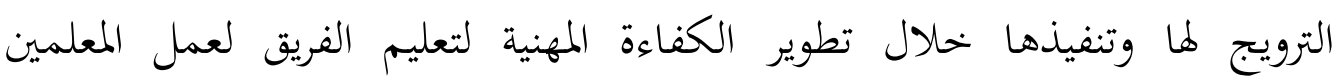

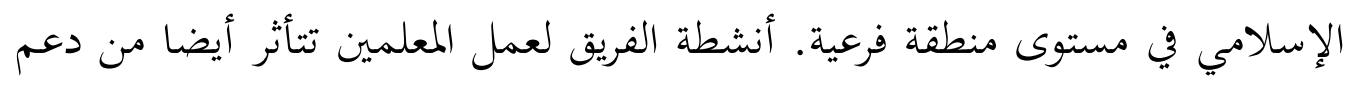

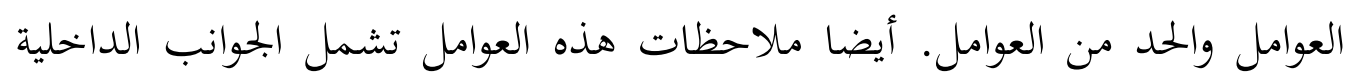
والخارجية.

Keywords: Profesionalisme Guru, Kegiatan Kelompok Kerja Guru 


\section{A. Pendahuluan}

Pendidikan merupakan investasi dalam pengembangan sumber daya manusia, dimana peningkatan kecakapan dan kemampuan diyakini sebagai faktor pendukung upaya manusia dalam menghadapi tuntunan zaman. Pendidikan yang dilaksanakan di Indonesia merupakan upaya terpadu dari segenap pelaksana pendidikan guna mencapai tujuan yang telah di tetapkan yaitu tujuan pendididkan Nasional. Tujuan tersebut disamping menjadi pedoman dalam penyelenggaraan pendidikan sekaligus menjadi sasaran kegiatan pendidikan.

Sekolahmerupakaninstitusipendidikanformalyangdalampenyelenggaraan pendidikan memerlukan personal sekolah, seperti harus ada guru/pendidik, tenaga administrasi dan kepala sekolah yang berkewajiban menyelenggarakan proses pendidikan di sekolah. Tugas guru antara lain sebagai pembimbing, penghubung, penegak disiplin, administrator, motivator, organisator, dan sebagainya. Guru menempati peranan kunci dalam mengelola pembelajaran, peranan ini akan di laksanakan apabila ia memiliki tingkat profesional yang baik. Kemampuan profesional guru tidak hanya di ukur dari kemampuan intelektual semata tetapi juga di tuntut untuk memiliki keunggulan dalam aspek moral, ketaqwaan, disiplin, tanggungjawab, kedalaman ilmu dan keluwesan wawasan kependidikan dalam mengelola kegiatan pembelajaran.

Dalam keseluruhan kegiatan pendidikan baik disekolah maupun diluar sekolah, guru memiliki posisi sentral dan strategis. Hal ini mengandung makna bahwa upaya reformasi pendidikan hanya dapat terwujud apabila unsur guru yang berada di front terdepan mendapat prioritas. Apabila unsurguru terabaikan maka upaya reformasi pendidikan bagaimanapun bagusnya, maka tidak akan mampu mencapai hasil yang optimal. Masalah guru baik dalam jumlah mutu, dan kesejahteraannya harus mendapat prioritas dalam keseluruhan pendidikan nasional, baik dari kepentingan pendidikan nasional maupun tugas fungsional guru, semuanya menuntut agar pendidikan dilaksanakan secara profesional artinya dilaksanakan secara sungguh-sungguh dan didukung oleh unjuk kerja yang profesional.

Peningkatan mutu pendidikan mutlak dilakukan oleh para guru, hal ini akan memberikan dampak terhadap mutu pendidikan nasional. Mutu pendidikan nasional dewasa ini menjadi sorotan berbagai pihak. Akan tetapi kita yakin dan percaya, bahwa tidak sedikitpun terlintas dihati para guru untuk tidak 
berupaya meningkatakan mutu pembelajarannya. Guru sudah berbuat banyak bagaimana kualitas proses pembelajarannya efektif dan hasil belajar anak akan baik. Oleh karena itu kemampuan profesional guru di sekolah dasar mutlak dimiliki, karena pada tingkat inilah kemampuan nalar, imajinasi, dan persepsi terbentuk. Pada kondisi ini, anak didik sangat dan sangat tergantung kepada guru-nya. Guru dapat diibaratkan nabi, karena apa yang disampaikan kepada anak didik, serta merta akan dikerjakan anak didiknya. ${ }^{1}$

Salah satu upaya yang dapat meningkatkan kompetensi profesional seorang guru dan mengembangkan pengetahuannya adalah aktif dalam proses pembelajaran dalam kegiatan kelompok kerja guru (KKG). Kelompok kerja guru (KKG) adalah wadah kegiatan profesional bagi guru SD/MI/SDLB di tingkat kecamatan yang terdiri dari sejumlah guru dari sejumlah sekolah. Selain itu upaya lain untuk mewujudkan guru profesional seperti: program sertifikasi (untuk meningkatkan kwalitas dan prasyarat kependidikan yang ditetapkan pemerintah.Untuk hal ini Dirjen Dikdasmen melalui keputusan No.079/C/ Kep/I/1993, tanggal 07 April 1993 menetapkan Pedoman Pelaksanaan Sistem Profesionalisme Guru Melalui Pembentukan KKG Bidang Studi di SD Sebagai Wahana Peningkatan Profesionalisme Guru SD. ${ }^{2}$

Melalui KKG diharapkan pembinaan kemampuan profesional guru menjadi maksimal dan mampu mencapai kompetisi. Lembaga yang berbentuk KKG ini merupakan institusi yang memberikan ruang terjadinya percepatan dan distribusi gagasan yang inovatif dan dinamis bagi pendidikan antara lain lewat pelatihan, rapat rutin, informasi dinas, qiraat, kegiatan sosial dan musyawarah yang di ikuti anggota KKG. Melalui forum KKG ini pula para guru bisa berbagi gagasan, sharing ide dan mencari pemecahan problem dari masalah dan kendala yang dihadapi dalam pelaksanaan tugas di sekolah sesuai dengan mata pelajaran agama Islam yang ditetapkan kurikulum.

Berdasarkan penelitian yang peneliti lakukan di KKG PAI kecamatan Samigaluh berbagai masalah yang muncul berkaitan dengan kegiatan KKG PAI terhadap profesionalisme guru PAI di kecamatan Samigaluh adalah di fokuskan pada beberapa hal sebagai berikut: 1). Minimnya sumber daya

1 Isjoni, Guru Sebagai Motivator Perubahan, (Yogyakarta: Pustaka Pelajar, 2009), hal.15

2 Dedi Supriyadi, Guru di Indonesia: Pendidikan, Pelatihan dan Perjuanggannya, Sejak Zaman Kolonial Hingga Era Reformasi, (Jakarta: Depdiknas, Dirjen Dikdasmen, Direktorat Tenaga Kependidikan, 2003), hal. 533. 
manusia yang dapat diandalkan dari kegiatan yang berlangsung. 2). Rendahnya animo para guru PAI terhadap program-program kerja yang disusun sehingga tingkat partisapasi menjadi rendah. 3). Kontribusi KKG bagi anggota yang aktif berpartisipasi dalam kegiatan secara signifikasi belum dapat meningkatkan keprofesionalisme guru PAI.

Masalahini harus ada perbaikan, berbagai tantangan dan problem yang dihadapi itu, sehingga diupayakan dapat diselesaikan melalui forum kelompok kerja guru (KKG) pendidikan agama Islam. KKG pendidikan agama Islam merupakan wadah/wahana pembinaan keprofesionalisme bagi guru yang bergabung dalam organisasi tersebut, dan diharapkan dapat meningkatkan mutu kualitas diri pendidikan pada umumnya, pendidikan yang bermutu dan juga di dukung oleh guru PAI yang professional.

Berdasarkan uraian pada latar belakang di atas rumusan penelitian ini adalah: Pertama, bagaimana upaya peningkatan profesionalisme guru melalui kegiatan kelompok kerja guru pendidikan agam Islam di kecamatan Samigaluh? Kedua, bagaimana faktor pendukung dan faktor penghambat dalam Upaya Peningkatan profesionalisme guru melalui kegiatan kelompok kerja guru pendidikan agam Islam di kecamatan Samigaluh?

Hasil penelitian ini diharapkan dapat digunakan untuk mengembangkan upaya peningkatan profesionalisme guru pendidikan agama Islam SD melalui kegiatan gugus, dan dapat sebagai masukan bagi para pengurus KKG dalam pengambilan kebijakan dan pengelolaan KKG agar program yang dikembangkan dapat relevan dengan kurikulum yang berlaku, sedangkan bagi guru pendidikan agama Islam dapat memberikan kontribusi positif dengan memanfaatkan KKG sebagai saran peningkatan profesionalisme dan mengembangkan dan meningkatkan kualitas pelaksanaan pendidikan dan kualitas lulusan di waktu yang akan datang.

\section{B. Metode Penelitian}

Penelitian ini dilaksanakan di kelompok kerja guru pendidikan Agama Islam di Kecamatan Samigaluh, Kabupaten Kulon Progo. jenis penelitian ini termasuk jenis penelitian lapangan (field research), yang dimaksud disini adalah penelitian tentang profesionalisme guru pendidikan agama Islam dalam kegiatan kelompok kerja guru (KKG) pendidikan agama Islam di kecamatan 
Samigaluh yang bertujuan menghimpun data dan informasi tentang masalah profesionalisme guru yang menjadi obyek penelitian.

Untuk penelelitian kualitatif, peneliti sekaligus berfungsi sebagai instrument (key instrument) yang terjun ke lapangan, berusaha sendiri untuk mengumpulkan informasi dengan melalui metode observasi yaitu metode pengamatan yang memiliki dua proses pengamatan dan ingatan. ${ }^{3}$, kedua metode wawancara yaitu percakapan dengan maksud tertentu. Percakapan itu dilakukan oleh dua pihak yaitu pewawancara yang mengajukan pertanyaan dan terwawancara yang memberikan jawaban atas pertanyaan itu ${ }^{4}$ dan metode yang ketiga adalah dokumentasi yaitu sumber informasi yang berasal bukan dari manusia (non human resurces).

Peneliti juga menggunakan teknik keabsahan data yaitu keabsahan data Untuk keabsahan data penulis penguji dengan teknik trianggulasi, dengan jalan membandingkan data hasil observasi, hasil wawancara, dan isi suatu dokumen yang berkaitan. Menurut Lexy J. Moleong pengertian trianggulasi adalah teknik pemeriksaan keabsahan data yang memanfaatkan sesuatu yang lain diluar data itu untuk keperluan pengecekan atau sebagai pembanding terhadap data itu. ${ }^{5}$ Trianggulasi adalah cara terbaik untuk menghilangkan perbedaan-perbedaan kontruksi kenyataan yang ada tentang berbagai kejadian dan hubungan berbagai pandangan. Dengan trianggulasi peneliti me-recheck temuannya dengan jalan membandingkannya dengan berbagai sumber, metode, atau teor

Analisapenelitiankualitatifmerupakanusahauntukmenatasecarasistematis dan sekelompok data yang telah diperoleh melalui observasi, wawancara, maupun dokumentasi. Analisis yang penulis gunakan adalah analisis interaktif dari Sanafiah Faisal. Menurutnya ada tiga kegiatan alur terjadi secara bersamaan dalam pengumpulan dan analisa data yaitu 1). Reduksi data yaitu proses pemilihan, perumusan, perhatian pada penyederhanaan atau mengangkat data dalam bentuk uraian atau lapangan yang terinci dan sistematis, menonjolkan pokok-pokok agar lebih mudah dikendalikan. 2). Penyajian data yaitu upaya menyajikan data untuk melihat gambaran keseluruhan data atau bagian tertentu dalam penelitian, penyajian data ini dibatasi sebagai sekumpulan informasi

3 Suharsismi Arikunto dan Cepi Safriudin Abdul Jabar, Evaluasi Program Pendidikan Pedoman Teoritis Bagi Praktisi Pendidikan, (Jakarta: PT Bumi aksara, 2007), hal.87.

4 Ibid, hal.186.

5 Lexy J. Moleong, Metodologi Penelitian Kualitatif, (Bandung: Remaja Rosdakarya, 1989), hal.330. 
tersusun yang memberikan kemungkinan adanya penarikan kesimpulan dan pengambilan tindakan. 3). Penggambaran kesimpulan (penarikan kesimpulan) adalah upaya untuk mencari makna terhadap data yang dikumpulkan dengan mencari pola tema hubungan persamaan hal-hal yang sering timbul dan sebagainya ${ }^{6}$.

\section{Pembahasan Hasil Penelitian}

KKG PAI pada dasarnya mempunyai peranan penting dalam mensosialisasikan berbagai usaha untuk mempersiapkan dan melaksanakan kurikulum. KKG PAI SD ini mempunyai fungsi sebagai berikut: 1). Forum komunikasi antar sesama guru pendidikan agama Islam dalam peningkatan kemampuan profesional dan fungsional. 2). Forum konsultasi yang berkaitan dengan kegiatan dan materi pembelajaran, metodologi, evalusi dan sarana penunjang. 3). Forum penyebarluasan informasi tentang segala kebijakan yang berkaitan dengan usaha-usaha pembaharuan dalam bidang pendidikan.?

Dari program kelompok kerja guru (KKG) PAI kecamatan Samigaluh dapat dilihat bahwa program kegiatan-kegiatan gugus berisi kemampuan dasar yang harus dimiliki oleh seorang guru pendidikan agama Islam (PAI) yang merupakan karakteristik guru yang profesional, yaitu kemampuan menguasai kurikulum, kemampuan menguasai materi pelajaran, menguasai metode pembelajaran, teknik evalusi, dan media pembelajaran, komitmen dalam tugas, dan disiplin dalam arti luas. Profesionalitas Guru Pendidikan Agama Islam antara lain adalah:

\section{Indikator kompetensi paedagogik}

Standar Kompetensi paedagogik guru sekolah dasar (Kompetensi Inti) meliputi: (1) menguasai karakteristik dari aspek fisik, moral, sosial kultural, emosional dan intelektual; (2) menguasai teori belajar dan prinsip-prinsip pembelajaran yang mendidik; (3) mengembangkan kurikulum yang terkait dengan mata pelajaran dalam bidang studi yang diampu; (4) menyelenggarakan pembelajaran yang mendidik; (5) memanfaatkan teknologi informasi dan komunikasi untuk kepentingan

\footnotetext{
6 Miller \& Hubermen, Analisa Data Kualitatif, (Jakarta: Universitas Indonesia, 1992), hal. 20.
}

7 Ibid, hal. 4. 
pembelajaran; (6) memfasilitasi pengembangan potensi peserta didik untuk mengaktualisasikanberbagaipotensiyang dimiliki; (7)Berkomunikasisecara efektif, empatik dan santun dengan peserta didik; (8) menyelenggarakan penilaian dan evalusi proses dan hasil belajar; (9) Memanfaatkan hasil penilaian dan evaluasi untuk kepentingan pembelajaran; (10) melakukan tindakan reflektif untuk peningkatan kualitas pembelajaran.

Dalam pembelajaran, guru hendaknya mempunyai kemampuan mengorganisir materi ajar, sumber media pembelajaran, membuat skenario pembelajaran sehingga tingkat kedalaman materi dapat direlevansikan dengan karakteristik peserta didik. Hal lain yang patut dimiliki guru adalah mampu memberikan ilustrasi dan pembahasan yang bisa dipahami siswa diimbangi dengan bimbingan individu terhadap peserta didik yang memiliki tingkat kemampuan khusus dan berbeda.

Adapun bahasan yang termasuk indikator kompetensi paedagogik dalam penelitian ini meliputi: Pemahaman terhadap peserta didik, Perancangan pembelajaran, Pelaksanaan pembelajaran, Evalusi hasil belajar, Aktualisasi dan pengembangan potensi peserta didik.

\section{Indikator kompetensi kepribadian}

Standar kompetensi kepribadian untuk guru SD mencakup: (1) Bertindak sesuai dengan norma agama, hokum, sosial dan kebudayaan nasional Indonesia; (2) menampilkan diri sebagai pribadi yang jujur, berakhlak mulia dan teladan bagi peserta dan masyarakat; (3) menampilkan diri sebagai pribadi yang mantap, stabil, dewasa, arif dan berwibawa; (4) menunjukkan etos kerja, tanggung jawab yang tinggi, rasa bangga menjadi guru dan percaya diri; (5) menunjung tinggi kode etik profesi guru.

Dari hasil penelitian tesis ini indikator kompetensi kepribadian meliputi: kemampuan kepribadian yang mantap dan stabil, dewasa, arif dan bijaksana, Sikap dan tutur kata guru akan berpengaruh alam keseharian peserta didik terutama saat di lingkungan sekolah, menjadi teladan bagi peserta didik, berakhlak mulia.

\section{Indikator kompetensi professional}

Standar kompetensi profesional untuk guru SD mencakup (a) Menguasai materi, struktur, konsep dan pola piker keilmuan yang mendukung 
mata pelajaran yang diampu; (b) Menguasai standar kompetensi dan kompetensi dasar mata pelajaran atau bidang pengembangan yang diampu, (c) Mengembangkan materi pembelajaran yang diampu secara kreatif; (d) Mengembangkan keprofesionalan secara berkelanjutan dengan melakukan tindakan reflektif; (e) Memanfaatkan teknologi informasi dan komunikasi dan pengembangan diri.

Dalam penelitian ini standar kompetensi profesional meliputi:

a. Mengerti dan dapat menerapkan landasan kependidikan

Guru yang profesional harus menguasai konsep-konsep, struktur dan metode keilmuan, teknologi dan berbagai kompetensi yang harus dimiliki oleh peserta didik melalui proses pembelajaran yang terjadi. Guru harus mampu memahami keterkaitan antara mata pelajaran baik yang $n$ profesional bersifat tematik maupun yang mandiri. Penguasaan guru dalam berbagai kemampuan profesional dalam konteks global dengan tetap memadukan antara perkembangan ilmu pengetahuan dengan nilai-nilai budaya nasional dalam proses pembelajaran.

b. Mengerti dan dapat menerapkan teori belajar sesuai dengan tingkat perkembangan perilaku peserta didik.

Guru profesional disyaratkan memiliki pengetahuan dan ketrampilan yang hanya dapat dikuasai dengan pendidikan tertentu dengan menggunakan teori dan metode ilmiah yang didasarkan pada disiplin ilmu yang jelas. Dalam pendidikan, aktifitas guru dan peserta didik adalah aktivitas belajar. Proses pembelajaran hendaknya berlangsung berdasarkan perkembangan psikologi peserta didik, yang menyangkut ciri-ciri anak didik, kematangan mental anak didik, kematangan jasmani, bahasa, intelektual, emosi dan social peserta didik maupun kebutuhan, keinginan, kecakapan, kemauan, perasaan dan sikap peserta didik. Karakteristik masing-masing peserta didik hendaknya diadopsi guru sebagai bahan dalam menentukan metode dan media yang tepat dalam menciptakan system pembelajaran yang kondusif.

Kemampuan untuk menerapkan teori belajar sesuai dengan kondisi peserta didik, kemampuan menghubungkan materi pembelajaran dengan pengalaman hidup aktual peserta didik dan selalu terbuka dalam 
memberikan kesempatan bertanya ataupun berpendapat kepada peserta didik tentang materi yang belum dimengerti merupakan dasar sifat positif yang dibangun guru untuk mengajarkan peserta didik untuk menghargai pemikiran orang lain. Kemampuan atas dasar teori dan konsep pendidikan secara utuh merupakan kemampuan ideal yang tidak dimiliki oleh setiap pendidik, kemampuan ini hanya diajarkan pada jenjang pendidikan tinggi

c. Mampu menangani mata pelajaran atau bidang studi yang ditugaskan kepadanya.

Seorang guru harus memiliki kemampuan akan tugas pokok dan fungsinya sebagai pendidik. Diantaranya menguasai kurikulum yang berlaku, standar kompetensi dan kompetensi dasar peserta didik, melakukan pemilahan dan pengelompokan terhadap bahan ajar yang digunakan sebagai materi pokok PAI serta mengembangkannya mampu mengaitkan antara materi belajar yang bersifat tematik pada kelas rendah dan materi non tematik pada kelas tinggi di sekolah dasar.

d. Mempunyai ketrampilan teknik mengajar

Untuk meningkatkan profesional guru minimal 15 point administrasi guru : (1) Membuat silabus; (2) Membuat program tahunan; (3) Membuat program semester; (4) Membuat rencana pelaksanaan pembelajaran (RPP); (5) mempunyai buku absen siswa; (10) Mempunyai buku supervisi; (11) Mempunyai buku bimbingan konseling; (12) Membuat analisis nilai; (13) Membuat analisis soal; (14) Mempunyai buku bank soal; (15) Membuat media pengajaran yang sesuai dengan kurikulum.

Dengan demikian diharapkan seorang guru memiliki kemampuan mengorganisir pembelajaran yang dilakukan baik dari segi peserta didik baik pengelompokan dalam diskusi dan penugasan mampu menggunakan media dan metode yang sesuai dan bervariasi untuk meningkatkan partisipasi peserta didik sehingga pembelajaran yang berlangsung bersifat menyenangkan, mampu mendesain alat penilaian yang sesuai untuk mengevaluasi pembelajaran sesuai dengan tujuan yang diinginkan. 
e. Mampu menumbuhkan kepribadian peserta didik

Proses pendidikan merupakan upaya pemberdayaan potensi peserta didik secara utuh meliputi aspek intelektual, emosi dan spiritual dengan tujuan utama pada proses perubahan perilaku peserta didik yang lebih baik. Pengelompokam aspek psikologis peserta didik dalam pencapaian tujuan belajar secara sempurna mencakup mengembangkan (a) Faktor kognitif meliputi kemampuan peserta didik dalam proses pembelajaran untuk mengetahui mengerti mengaplikasikan, menganalisis mensistesiskan dan mengevaluasi materi pelajaran; (b) Faktor afektif meliputi kemampuan peserta didik dalam menerima merespon mengorganisasikan nilai hidup dan mewatak; (c) Faktor psikomotorik, meliputi kemampuan peserta didik pada proses pembelajaran dalam mengindra menyiagakan diri bertindak terpimpin bertindak mekanik dan bertindak kompleks.

Guru PAI harus mampu memadukan kemampuan kognitif, afektif, dan psikomotorik peserta didik dengan materi dalam kurikulum yang berlaku, sehingga standar kelulusan yang diharapkan dengan tujuan pendidikan dasar dapat terwujud dengan baik. Kemampuan guru dalam memadukan kemampuan yang dimiliki peserta didik juga harus diimbangi dengan sikap dan tindakan guru yang sesuai dengan normanorma yang berlaku. Dari sini diharapkan setiap tindakan guru akan berpengaruh positif pada peserta didik, mampu menumbuhkan dan membangun sikap toleran dan saling menghargai dalam mensikapi perbedaan yang ada, baik perbedaan pola hidup, social dan agama.

\section{Indikator kompetensi sosial}

Menurut Peraturan Menteri Pendidikan Nasional No.16 tahun 2007 tentang standar Kualisasi Akademik dan Kompetensi Guru dijelaskan bahwa standar kompetensi social untuk guru SD mencakup (1) Bersikap inklusif, bertindak obyektif serta tidak diskrimainatif karena pertimbangan jenis kelamin, agama, ras, kondisi fisik, latar belakang keluarga dan status sosial ekonomi; (2) Berkomunikasi secara efektif, empati dan santun dengan sesame pendidik, tenaga kependidikan, orang tua dan masyarakat; (3) Beradapatasi ditempat tugas di seluruh wilayah republik Indonesia yang memiliki keragaman sosial budaya; (4) Berkomunikasi dengan komunitas 
profesi sendiri dan profesi lain secara lisan dan tulisan atau bentuk lain.

Undang-undang pendidikan RI No.20/2003 tentang sistem pendidikan nasional (Sisdiknas) menjelaskan bahwa pendidikan adalah tanggung jawab keluarga, masyarakat dan pemerintah. Oleh sebab itu, ketiga komponen ini bertanggungjawab terhadap pendidikan.

Peranan sekolah terhadap input peserta didik antara lain seleksi di sekolah, dimonitoring komite sekolah, mengevaluasi mutu sekolah untuk membangun akuntabilitas sekolah, mensubsidi langsung peserta didik dan proses pendidikan termasuk kurikulum sebaiknya direncanakan oleh komite sekolah yang mewakili masyarakat, sekolah dan pemerintah daerah. Peranan pemerintah antara lain menyediakan standar kompetensi untuk semua jenis dan jenjang pendidikan, menhilangkan keterlibatan pemerintah dalam implementasi proses pendidikan termasuk sleksi dan evaluasi peserta didik dan mendirikan unit yang menangani pengaduan. Peran dewan pendidikan antara lain menetapkan kriteria seleksi peserta didik baru dan menyeleksi peserta didik keluarga miskin yang berhak memperoleh subsidi pemerintah. Peran komite sekolah adalah mengimplemantasikan proses seleksi peserta didik dan melaksanakannya audit kinerja eksternal pada sekolah.

Adapun indikator kompetensi sosial dalam penelitian ini meliputi:

a. Bergaul secara efektif dengan peserta didik

Interaksi yang terjadi antara guru dan peserta didik terjadi baik dalam lingkungan sekolah maupun di luar sekolah. Guru diharapkan meluangkanwaktunyadiluarjamsekolahuntukmelalukan pemantauan terhadap perkembangan peserta didik, sehingga dengan informasi dan data tentang peserta didik yang dimiliki guru akan memudahkan guru dalam membuat suatu keputusan yang tepat untuk siswa, terurama berkaitan dengan bimbingan kesulitan belajar, problem pribadi peserta didik, antar peserta didik dan peserta didik dengan keluarga.

Guru sebaiknya tetap dekat dengan siswa untuk memahami karakteristik peserta didik disamping untuk member pengaruh positif terhadap peserta didik dalam setiap ucapan, tindakan dan kebisaaan kebisaaan yang baik. Walaupun ada asumsi bahwa guru dekat dengan peserta didik akan mengurangi wibawa guru didepan peserta didik 
merupakan suatu keharusan untuk mencapai tujuan yang diharapkan, tetapi jangan terlalu dekat dengan standar guru mempunyai batasanbatasan tertentu sehingga kewibawaan guru tetap terjaga, misalanya dalam mengatasi peserta didik yang nakal harus dengan pendekatanpendekatan tertentu.

b. Mampu bekerja sama dengan sesama pendidik dan tenaga kependidikan

Hubungan yang terjadi dalam sebuah lembaga pendidikan diibaratkan seperti hubungan keluarga. Dimana antara satu guru dengan guru yang lainnya saling membutuhkan dan tidak dapat berdiri sendiri, terutama dalam menegakkan suatu aturan dan kedisiplinan demi kebaikan dan kemajuan bersama. Hal-hal penting untuk membangun kerjasama dengn sesama guru adalah adanya komitmen, sikap saling percaya, saling menghormati dan menghargai tanpa memandang status dan komunikasi. Pentingnya kerjasama dengan sesame guru termasuk guru PAI (baik interen maupun eksteren sekolah) terutama dalam membahas berbagai masalah yang berkaitan dengan pembelajaran agar diperoleh situasi yang tepat, kepedulian untuk saling pengertian dan bertanggungjawab, seperti jika berhalangan dalam menjalankan tugas atau jika tidak ada guru piket ataupun guru karena hal lain yang sifatnya mendadak. Berdiskusi dengan sesame guru untuk meningkatkan kemampuan, wawasan dan keilmuan yang berkaitan dengan profesi guru.

c. Menjalin hubungan dan kerjasama dengan orang tua atau wali peserta didik.

Keberadaan orang tua sangat penting artinya bagi peserta didik dan sekolah. Dengan demikian guru harus mampu menjalin relasi dengan orang tua murid, sehingga mereka menjadi mitra guru dan sekolah dalam proses pendidikan, karena kerjasama diantara dua elemen tersebut sangat urgen dalam membentuk kepribadian peserta didik.

Dalam rangka meningkatkan kualitas pendidikan seseorang pendidik harus melakukan kerjasama dengan orang tua murid dan 
masyarakat perantara melalui komite sekolah. Komite sekolah memiliki fungsi sebagai berikut : a) mendorong tumbuhnya perhatian dan komitmen masyarakat terhadap penyelenggaraan pendidikan yang bermutu; b) melakukan kerjasama dengan masyarakat (perorangan/ organisasi/dunia usaha/dunia industry) dan pemerintah, berkenanaan dengan penyelenggaraan pendidikan yang bermutu; c) menampung dan menganalisis aspirasi ide, tuntunan, dan berbagai kebutuhan pendidikan yang diajukan masyarakat; d) memberikan masukan, pertimbangan dan rekomendasi kepada Rencana Anggaran Pendidikan dan Belanja Sekolah (RAPBS), criteria kinerja satuan pendidikan, criteria tenaga kependidikan, criteria fasilitas pendidikan dan hal-hal yang terkait dengan pendidikan; e) mendorong orangtua dan masyarakat berpartisipasi dalam pendidikan guna mendukung peningkatan mutu dan pemerataan pendidikan; f) menggalang dana masyarakat dalam rangka pembiayaan penyelenggaraan pendidikan disatuan pendidikan; g) melakukan evaluasi dan pengawasan dalam rangka pembiayaan penyelenggaraan pendidikan disatuan pendidikan.

d. Bergaul secara santun dan menempatan diri sesuai dengan tugas dan fungsinya dilingkungan masyarakat.

Guru sebagai pendidik dalam hidup kesehariannya akan selalu dinilai menjadi panutan bagi masyarakat oleh karena itu guru harus mampu menempatkan diri dalam bersikap dan berperilaku sesuai norma-norma agama dalam hidup bermasyarakat. Merupakan sebuah kepuasan tersendiri bagi guru jika mampu menyumbangkan ilmu dan pikirannya yang berupa pendapat dan ide-ide yang berguna untuk kemajuanmasyarakat.Sesuai perandanfungsisertaketeladanan seorang guru maka mengitip pendapat Sosrokartono untuk menggambarkan keagungan guru bahwa guru itu sugih tanpa bondo artinya kaya tanpa mempunyai harta benda, ngulug tanpa bala artinya mendatangi lawan tanpa bala tentara, menang tanpa ngasorake artinya menang tanpa mengalahkan, weweh tanpa kelangan artinya memberi tanpa kehilangan ilmu yang dimilikinya. 


\section{Faktor pendukung dan faktor penghambat yang mempengaruhi pening- katkan profesionalisme guru pendidikan agama Islam}

Faktor-faktor yang mempengaruhi dalam peningkatan profesionalisme guru melalui KKG PAI ini dikelompokkan menjadi dua kelompok, yaitu faktor internal dan faktor eksternal. Faktor internal yaitu faktor-faktor yang ditimbulkan oleh diri pribadi masing masing. Faktor ini sangat dominan karena bersifat langgeng, muncul dari dalam diri pribadi masing masing. Yang termasuk faktor ini antara lain yaitu motivasi. Sedang faktor eksternal yaitu faktor-faktor yang mempengaruhi karena ada rangsangan dari luar. Faktor pendukung pengembangan profesionalisme guru pendidikan agama Islam di KKG PAI kecamatan Samigaluh kesadaran para guru dalam mengikuti program pelatihan dan mengikuti studi lanjut kegiatan KKG. Supaya menjadi guru profesionalisme para guru agama di wilayah kecamatan Samigaluh, mereka selalu berusaha untuk mengikuti kegiatankegiatan pengembangan profesionalisme guru pendidikan agama Islam yang di selenggarakan pihak sekolah maupun dari luar sekolah.(1) Untuk faktor internal yaitu adanya semangat dan motivasi yang tinggi dari peserta KKG PAI kecamatan Samigaluh, adanya pembinaan dan monitoring dari MAPENDA baik kabupaten maupun kecamatan. Untuk pembinaan setiap tahunnya di adakan lomba gugus tingkat Kabupaten yang diikuti oleh wakil wakil dari tingkat kecamatan, disamping adanya bantuan operasional gugus dari kementerian Agama tingkat kabupaten (2). Untuk faktor eksternal dampak dari wokshop ataupun pelatihan-pelatihan yang sering diikuti diharapkan bukan hanya berdampak mendapatkan energi baru, karena hanya berlangsung sesaat, dan sesudah itu para peserta latihan ketika berada/beraktifitas di gugus kembali ke kebisaaan lama mereka sebelum pelatihan. Sehingga diperlukan suatu pelatihan yang dilakukan secara berulang-ulang atau berkesinambungan sehingga menjadi sebuah karakter yang diharapkan.

Sedangkan Faktor penghambat yang mempengaruhi peningkatkan profesionalisme guru PAI dapat di lihat dari berbagai permasalahan/ problem yang sering dihadapi pada kegiatan kelompok kerja guru (KKG) kecamatan Samigaluh ini semua menjadi tanggung jawab semua pengurus dan anggota KKG PAI kecamatan Samigaluh, berbagai permasalahan ini 
dicarikan solusinya, diselesaikan dan penyelesainya melalui forum KKG PAI, sebagaimana Faktor internal masalah pimpinan sekolah yang berbeda agama, ini bisa disiasati dengan meminta izin ketika mau mengadakan kegiatan KKG, jarak tempuh, ini bisa disiasati dengan datang lebih awal, karena jarak tempuh yang cukup jauh ini dhadapi oleh setiap guru, sarana dan parasaranayang kurangmemadai, kemampuandasarguruyang sifatnya heterogen, administrasi pendidikan yang terus berganti dan kemampuan dasar guru yang minim tentang penelitian, kalau tanpa usaha untuk mencari solusi atau jalan penyelesainnya, atau mempelajari pengalaman orang lain yang senasib, maka akan senantiasa menjadi persoalan yang tidak aka nada penyelesainnya, namun melalui forum KKG PAI ini kendala yang sering dihadapi para anggotanya bisa dimusyawarahkan dengan cara bertukar pikiran, pendapat maupun saling membantu dan bekerja sama untuk dicari jalan keluar atau solusinya. Kendala lain yang agak riskan adalah banyaknya kecemburuan dari para peserta KKG yang aktif mengikuti kegiatan dengan peserta yang tidak aktif, hal ini dikarenakan dalam kegiatan KKG PAI di kecamatan Samigaluh semua peserta KKG PAI diberikan surat keterangan kepada anggota KKG tanpa kecuali, karena surat keterangan tersebut bisaanya digunakan untuk lampiran mengajukan usul kenaikan pangkat, hal ini disiasati dengan himbauan kepada setiap peserta/anggota KKG PAI Samigaluh agar selalu mengikuti kegiatan yang diadakan KKG PAI tanpa kecuali, sehingga kecemburuan peserta yang aktif dengan yang tidak aktif dapat terhindari.

Sedangkan penghambat dari faktor eksternal ini yaitu kurangnya kegiatan wokshop dan pelatihan bagi para guru PAI ini dapat disiasati dengan memohon kepada pengawas PPAI untuk mengusulkan kepada Kementerian agama agar mengagendakan kegiatan wokshop maupun pelatihan bagi para guru PAI agar dapat lebih meningkatkan kinerja yang nantinya berimbas kepada keprofesionalisme keguruannya. Hal ini menunjukkan bahwa keberadaan forum KKG PAI dapat membantu meningkatkan profesionalisme guru para anggotanya, terutama melalui keaktifan dalam mengikuti kegiatan KKG PAI dan senantiasa aktif melaksanakan program kegiatan yang telah ada oleh pengurus KKG maupun yang dijadwalkan oleh Kantor Kementerian Agama tingkat 
Kabupaten, ataupun program kegiatan yang diselenggarakan oleh berbagai bentuk, dengan hal ini diharapkan bisa senantiasa di ikuti dan dilaksanakan dengan sebaik-baiknya.

Pengetahuan ataupun ketrampilan yang masih minim yang dimiliki oleh seorang guru pendidikan agama Islam ini dapat diupayakan melalui kegiatan KKG PAI ini, sehingga ketika sudah aktif mengikuti kegiatan KKG PAI ini diharapkan akan menjadi tahu dan terampil, ataupun memberikan wawasan yang lebih luas untuk bekal peningkatan kemampuan seorang guru terutama guru mata pelajaran pendidikan agama Islam dimana ia ditugaskan. Profesionalisme guru seorang guru dapat dilengkapi dengan kecakapan dianogtik dan kemampuan aplikatif, apabila suasana pembelajaran kurang mendukung dengan baik, guru akan menciptakan suasana yang dapat menjamin keberlangsungan proses pembelajaran yang baik, kreatif dan inovatif, baik dengan kemampuannya sendiri maupun dengan menggali pengalaman dari orang lain, dan ini hanya akan dapat ketika para guru PAI tersebut aktif mengikuti kegiatan KKG, dan saling bertukar pengalaman dengan para guru-guru PAI yang lain, harapannya seluruh komponen pembelajaran pendidikan agama Islam yang menjadi tugas pokoknya bisa dilaksanakan dengan sebaik-baiknya dan terpenting bisa meningkatkan profesionalismenya sebagai guru pendidikan agama Islam yang unggul, mampu mendidik dan mengajar peserta didik dengan sebaik-baiknya sehingga hasil akhir yang diharapkan setiap anak didik mampu memperoleh nilai yang maksimal dalam pengetahuan khususnya mata pelajaran pendidikan agama Islam dan dapat lulus dengan hasil yang memuaskan pula.

Tindak Lanjut yang diupayakan sebagai solusi dari faktor penghambat darikegiatan di KKGPAI kecamatanSamigaluha).Supervisi danmonitoring b). Upaya mengimplementasikan tema sentral pendidikan Agama Islam, c). Berkomitmen meningkatkan profesional guru pendidikan agama Islam melalui KKG, d). Meningkatkan standar akademik guru profesional bagi guru pendidikan agama Islam, e). Mengoptimalkan hasil lomba MAPSI (Mata Pelajaran dan Seni Islami) f). Peningkatan dan pengembangan mutu kemampuan guru profesional yang lebih luas 


\section{Penutup}

Upaya peningkatan profesionalisme guru melalui kegiatan kelompok kerja guru pendidikan agama Islam di wilayah kecamatan Samigaluh tergolong baik, karena pelaksanaannya telah sesuai dengan pedoman dan rambu-rambu pengembangan kegiatan KKG yang ada. Guru-guru yang tergabung dalam anggota KKG PAI kecamatan Samigaluh telah memiliki kompetensi profesional yang meliputi 4 unsur kompetensi yaitu kompetensi paedagogik, kompetensi kepribadian, kompetensi profesional, dan yang terakhir kompetensi sosial

Di dalam peningkatan profesionalisme guru di temukan adanya dua faktor pokok yaitu faktor pendukung dan faktor penghamat. Baik faktor pendukung maupun penghambat dalam kegiatan KKG PAI di kecamatan Samigaluh di bagi menjadi faktor internal dan faktor eksternal, demikian pula pada faktor penghambatnya yakni faktor internal dan faktor eksternal. Untuk lebih jelasnya dari faktor pendukung internal ini antara lain adalah motivasi para peserta KKG, dan adanya monitoring dari MAPENDA kabupaten maupun pengawas PPAI tingkat kecamatan sedangkan faktor eksternalnya adalah kesadaran para guru dalam mengikuti wokshop maupun pelatihan-pelatihan dalam rangka untuk peningkatan kompetensi profesional guru pendidikan agama Islam.

Faktor penghambat internal diantaranya kendala pimpinan yang berbeda agama, sarana/prasarana yang kurang tersedia dalam pembelajaran, jarak tempuh antara sekolah dengan tempat kegiatan KKG, dan pengetahuan para anggota KKG yang sangat minim. Sedang faktor eksternal yang menjadi penghambat adalah kurangnya ketersedian woksop maupun pelatihan bagi guru PAI dalam rangka peningkatan kompetensi profesional guru. Semua hal ini dapat disiasati dengan saling komunikasi dengan rekan kerja, datang lebih awal, mempelajari pengalaman orang lain, saling berdiskusi, bertukar pikiran, saling membantu dan bekerja sama dengan anggota KKG PAI lainnya, sehingga diharapkan dapat mencari solusi dari permasalahan tersebut melalui forum KKG PAI tingkat kecamatan. 


\section{DAFTAR PUSTAKA}

Dedi Supriyadi, 2003, Guru di Indonesia. Pendidikan, Pelatihan dan Perjuanggannya, Sejak Zaman Kolonial Hingga Era Reformasi, Jakarta, Depdiknas, Dirjen Dikdasmen, Direktorat Tenaga Kependidikan.

Isjoni. 2009. Guru Sebagai Motivator Perubahan, Yogyakarta, Pustaka Pelajar

Moleong, L J. 1989. Metodologi Penelitian Kualitatif, Bandung, Remaja Rosdakarya.

Miler \& Hubermeman. 1992. Analisa Data Kualitatif, Jakarta, Universitas Indonesia.

Arikunto, Suharsismi dan Cepi Safriudin Abdul Jabar. 2007. Evaluasi Progam Pendidikan Pedoman Teoritis Bagi Praktisi Pendidikan, Jakarta, PT Bumi aksara. 
220 Millah Vol. XIV, No. 2, Februari 2015 